\title{
Statistical Literacy of Pre-Service Islamic Religious Education Teachers
}

\author{
Dede Salim Nahdi ${ }^{1}$, Nurudin Araniri ${ }^{2}$, Mohamad Gilar Jatisunda ${ }^{3}$, Yeni Dwi Kurino ${ }^{4}$, Ujiati \\ Cahyaningsih $^{5}$ \\ Universitas Majalengka \\ J1. KH. Abdul Halim No. 103 Majalengka, Indonesia \\ salimnahdi@unma.ac.id
}

\begin{abstract}
Statistics in education are useful for solving problems faced by teachers in classroom learning activities, such as collecting test result data, processing them, and presenting them in a report card. Therefore, prospective teachers need to have good statistical literacy skills. However, many prospective teachers still have difficulty understanding it, especially those who do not have a good background in math skills. This condition occurs in prospective teachers in the Islamic Religious Education department. This study aims to describe the statistical literacy of prospective teachers in the Islamic Religious Education Department based on statistical literacy indicators. The research is expected to describe the statistical literacy skills of students so that they can be used as material for further research. This research uses the descriptive qualitative method. The subjects in this study were 32 students. Data collection was carried out by providing statistical literacy tests. The results showed that $81.25 \%$ of students were able to understand statistical data which was displayed in the form of a line diagram; $87.50 \%$ of students can present the data in the appropriate diagram, and only $37.50 \%$ of students are able to interpret the data from the given cases.
\end{abstract}

Keywords: statistical literacy; pre-service teachers; islamic religious education

Abstrak
Statistik dalam pendidikan berguna untuk memecahkan masalah yang dihadapi guru dalam kegiatan pembelajaran di kelas, seperti mengumpulkan data hasil tes, mengolahnya, dan menyajikannya dalam buku raport. Oleh karena itu, calon guru perlu memiliki keterampilan literasi statistik yang baik. Namun, banyak calon guru masih kesulitan memahaminya, terutama mereka yang tidak memiliki latar belakang keterampilan matematika yang baik. Kondisi ini terjadi pada calon guru di jurusan Pendidikan Agama Islam. Penelitian ini bertujuan untuk mendeskripsikan literasi statistika calon guru di Jurusan Pendidikan Agama Islam berdasarkan indikator literasi statistika. Penelitian ini diharapkan dapat mendeskripsikan keterampilan literasi statistika mahasiswa sehingga dapat digunakan sebagai bahan penelitian selanjutnya. Penelitian ini menggunakan metode kualitatif deskriptif. Subjek dalam penelitian ini adalah 32 siswa. Pengumpulan data dilakukan dengan memberikan tes literasi statistik. Hasil penelitian menunjukkan $81,25 \%$ siswa mampu memahami data statistik yang ditampilkan dalam bentuk diagram garis; $87,50 \%$ siswa dapat menyajikan data dalam diagram yang sesuai, dan hanya $37,50 \%$ siswa yang mampu menginterpretasikan data dari kasus yang diberikan.

Kata kunci: statistik literasi, calon guru, pendidikan agama islam

Copyright (c) 2021 Dede Salim Nahdi, Nurudin Araniri, Mohamad Gilar Jatisunda, Yeni Dwi Kurino, Ujiati Cahyaningsih

$\square$ Corresponding author: Dede Salim Nahdi

Email Address: salimnahdi@unma.ac.id (J1 KH. Abdul Halim No. 103 Majalengka)

Received 22 January 2021, Accepted 07 March 2021, Published 09 April 2021

\section{INTRODUCTION}

Statistics played a very important role in various human activities during the industrial revolution 4.0 era. Statistics has become one of the key areas of study in the modern world of information and big data. Statistical literacy has been recognized as an important knowledge to be practiced by all people in today's information society (Yotongyos et al., 2015). Statistics have become an important component of the mathematics curriculum in the last three decades (Franklin et al., 2007). There has been a great interest in the field of Statistics Education. Learning statistics are concerned with ensuring that students understand statistical ideas and are able to apply them in real world situations (Reid \& Petocz, 2002; 
Statistical literacy of pre-service Islamic religious education teachers, Dede Salim Nahdi, Nurudin Araniri, Mohamad Gilar Jatisunda, Yeni Dwi Kurino, Ujiati Cahyaningsih

Songsore \& White, 2018; Tishkovskaya \& Lancaster, 2010) . According to recent studies (Chance, 2002; Gal, 2002; Joan Garfield \& Gal, 1999; Schield, 2004; Pfannkuch \& Wild Chris, n.d., 1999; delMas, 2002), there has been intensive research regarding statistical thinking, statistical literacy and statistical reasoning. The three notions, statistical literacy, statistical reasoning and statistical thinking, are inherently fuzzy and unambiguous in defining and discriminating from one another (Nikiforidou et al., 2010).

Advances in technology and modern methods of data analysis and increasingly easy access to information led to the development of materials focused on the introduction of statistical concepts in the primary school curriculum. In recent years, there have been an expansion and renewal of the statistics content in the mathematics curricula in many countries through all school grade levels from primary to secondary levels (Newton et al., 2011). "Data Analysis and Probability" as one of the five standard content contents (Principles, 2000). In the United States, Secretary's Commission on Achieving Necessary Skills (of Labor. Secretary’s Commission on Achieving Necessary Skills, 1991), recommends establishing a benchmark to inform statistical education at the secondary level as a provision for students in the world of work ( $\mathrm{Gal}, 2002)$ concern was about adults in society, as was that of (Wallman, 1993; Moreno, 2002; Utts, 2003; Scheaffer, 2003). There is broad agreement that in an increasingly quantitative world having an understanding of statistical information and being able to interpret and act on that information is essential (for Europe \& of the European Communities, 2007). Petty describes the use of social media as a medium to convey the message of the importance of statistical literacy for students and the wider community (Petty, 2010; Makar et al., 2014).

In Indonesia, Statistics is one of the materials that students must learn. Statistics is even studied at all levels of education, from primary education to higher education. In higher education, statistics are given to students as a provision of knowledge in the research process that they will do, starting from research planning, data collection process, data analysis, to making conclusions (Nurizzati, 2014). Current research trends and challenges in statistical education emphasize the learning process, teaching, and the design of learning trajectories (Ben-Zvi \& Makar, 2016; Jatisunda et al., 2020). Statistics equips students to have the ability to think logically, critically, creatively, and systematically and be able to produce individuals who can carry out research (Wahyuni \& Fauziah, 2015). Statistics acts as a tool to handle quantitative data obtained from research (Munah Hartuti \& Widyasari, 2016) Statistics learning in Higher Education aims to make students aware of the importance of understanding data; can understand the basic concepts of statistics and their terminology; know how to collect data and the ability to describe it; have data interpretation skills, and as a basis for communication (Rumsey, 2002). For prospective teacher students, statistics are important for solving learning problems in class. In statistics education is needed starting from the activities in the laboratory, research to various activities in the management of learning (Sariningsih \& Herdiman, 2017). Statistics are important to be understood by prospective teacher students so that they can respond, understand, analyze, interpret, and make conclusions about various information related to statistics and can give meaning to problems raised 
through statistical information in various literacy media (Johannis Takaria \& Talakua, 2018). Students will be familiar with statistical activities, begin to get used to thinking statistics, and take a statistical stance, so students will have a statistical tendency (attitude) in solving problems and making decisions about the problems they face. Once the importance of the benefits of statistics for students, the understanding of statistics needs to be a concern. Students need to have statistical literacy skills, not only to complete their studies, more than that statistical literacy is needed when they enter the workforce.

Statistics Literacy is the ability to comprehend and evaluate critically the results of statistics that occur in our daily lives (Kilpatrick, 1993). Statistical literacy is the ability to understand statistical language: words, symbols, and terms. Able to interpret graphs and tables, and be able to read and understand statistics in the news, media, polls, etc. (Garfield, 1999; Hovermill et al., 2014; Takaria \& Rumahlatu, 2016). Statistical literacy includes basic and primary skills that can be used in understanding statistical information or research results. These skills include being able to manage data, create and present tables, and work with different data interpretations. Statistical literacy also includes understanding concepts, vocabulary, and symbols, as well as an understanding of probability as a measure of uncertainty (Ben-Zvi, D. \& Garfield, 2004). Hayden defines statistical literacy as the skills a person needs to deal with probability and statistical problems that arise in everyday life (Hayden, R., n.d.). Statistical literacy involves creating, evaluating and using products that use words, numbers, and graphs together to communicate messages. It includes skills in making and using these products ( $\mathrm{S}$ Forbes, M Camden, n.d.). Having statistical literacy will provide comfort in making quantitative decisions that arise on a job and other issues in life (Moh. Hafiyusholeh, n.d.).

If examined more deeply, one of the goals of statistics courses is statistical literacy. Therefore, the purpose of this study is to describe how students' statistical literacy is by analyzing student answers following the indicators of statistical literacy abilities that have been set.

\section{METHOD}

This research is a descriptive qualitative study, research that describes in full the social setting to explore and clarify a phenomenon, by describing the measured variables (Gall et al., 1996). This research is a case study of 28 participant of Islamic Education students of one of the universities in Majalangka in 2019. This research instrument is a question made based on statistical literacy indicators. Data were collected through analysis of the Midterm Examination. To obtain the validity of the data from the statistical literacy test results, data triangulation was carried out, namely by conducting observations and interviews with research subjects regarding the answers that had been written. Interviews were conducted using a structured interview guide to investigate statistical literacy skills. The process of data analysis in this study refers to with the steps of data reduction (Miles et al., 1994), data exposure, and drawing conclusions and verification. 


\section{RESULT AND DISCUSSION}

To explore and describe the statistical literacy of prospective teacher students in reading statistical data, presenting statistical data, and presenting the results of statistical data processing, the statistical literacy test task is given as follows: In general, the results of students' statistical literacy abilities as presented in Table 1.

Table 1. Statistics Literacy Capabilities

\begin{tabular}{|l|c|}
\hline Indicator & Percentage \\
\hline Understanding statistical data & $81.25 \%$ \\
Present statistical data & $87.50 \%$ \\
Present the results of statistical data processing & $37.50 \%$ \\
\hline
\end{tabular}

\section{Understanding statistical data}

In this statistical literacy indicator students are required to be able to describe the data displayed in a line diagram. This is to stimulate student communication skills in writing and develop the ability to describe data according to the graphical info provided. Following are the problems given in the indicator (see picture 1).

1. Diagram berikut menggambarkan perbandingan tren penjualan produk elektronik desktop, laptop, dan tablet dalam enam bulan terakhir

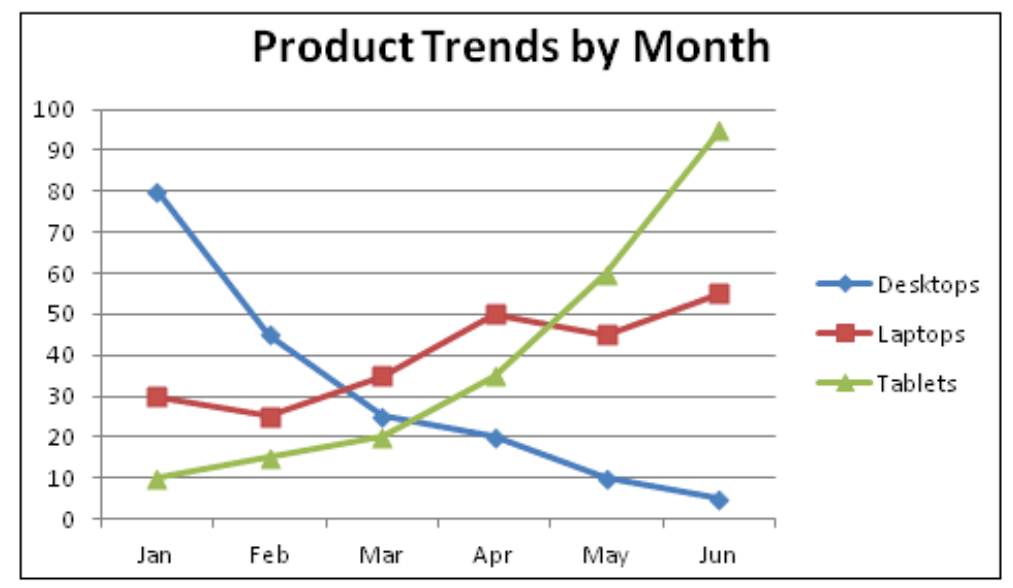

Bagaimana tafsiran saudara mengenai data di atas? Kesimpulan apa yang dapat ditarik?

Picture 1. Questions for indicators of understanding statistical data

In the question above (picture 1), students are asked to make interpretations of the data presented in the graph and make conclusions.

Based on the results of students in answering these questions, as much as $81.25 \%$ of students are able to describe complete data starting from extreme data that is maximum and minimum for each electronic product, to conclude the sales trends of the three products. This shows that students are able to communicate in writing well. The remaining $18.75 \%$ have not been able to provide analysis and conclusions. They only describe improvise, namely only describing tablets as electronic products that 
have the best sales trends without adding descriptions and more detailed analysis related to the data presented.

Based on the results of observations on students who have difficulty with this problem it is identified that these students tend to be less active in class or in discussion groups. In addition, the initial ability factor, namely the ability of mathematics to support the acquisition of statistical concepts they have, is still weak.

\section{Present Statistical Data}

In this statistical literacy indicator students are required to understand information from the data displayed and present it again in the form of an appropriate graph. This process requires accuracy in understanding the characteristics of the data. Whether the data presented is continuous or categorical data. Here is a matter of the statistical literacy indicator (see picture 2).

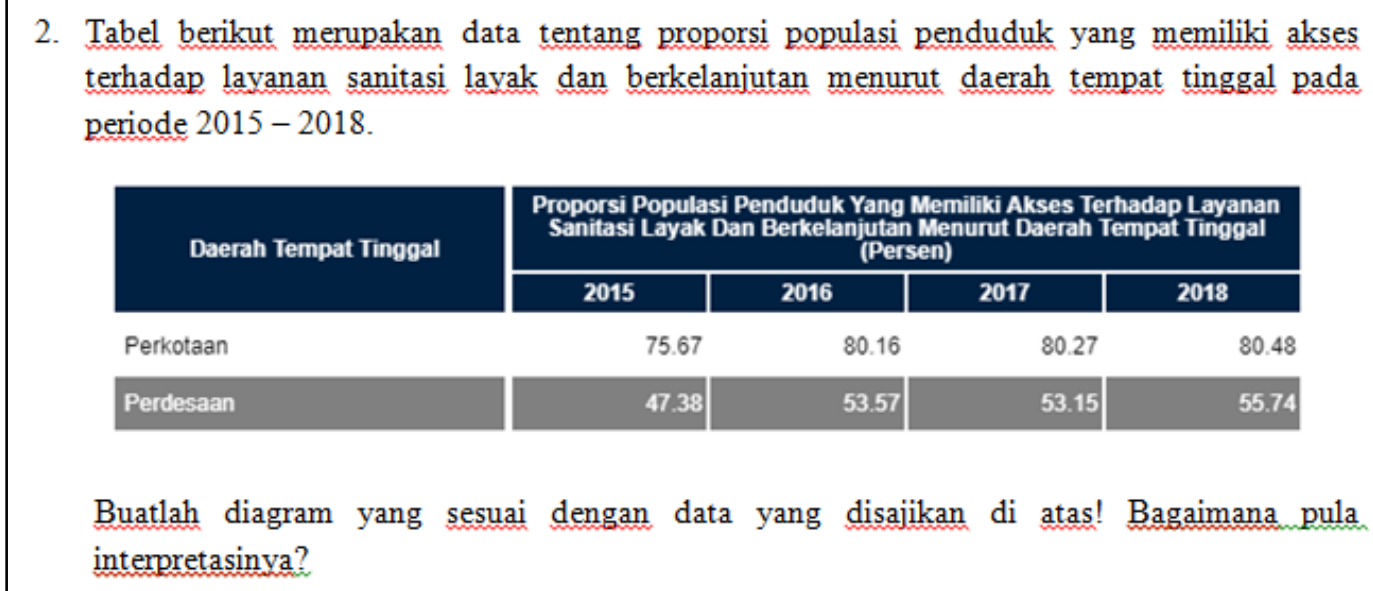

Picture 2. Questions for indicators of present statistical data

The above question (picture 2) illustrates data on the proportion of Indonesia's population that has access to proper and sustainable sanitation services during the 2015-2018 period based on their residence. In this problem, students are asked to change the data presented in the table into diagrams and make interpretations of the data provided.

Based on the results of student tests in answering these questions, as much as $87.50 \%$ of students are able to present the data provided in the form of line charts. While $12.50 \%$ of students are still mistaken in presenting data in the appropriate diagrams. They make the mistake of presenting data through bar charts and pie charts. This shows that students are not careful in understanding the characteristics of the data. If referring to the data in the table given in the problem, the data shows continuity in terms of time, so that when it will be presented in the form of diagrams, the most appropriate diagram is to use a line diagram. Through the line diagram can be seen progress variables that are observed from time to time during a certain period. 


\section{Present The Results of Statistical Data Processing}

This statistical literacy indicator, students are required to provide logical arguments about a given case. To solve this problem students are asked to use various data sizes to arrive at the correct conclusion. Here are the problems with the indicator (see picture 3.).

3. Pak Amin adalah seorang pedagang yang menjual bakso dan es campus. Selama bulan Agustus rata-rata keuntungan penjualan bakso dan es campur berturut-turut adalah 725.000 dan 525.000 dengan simpangan baku masing-masing 55.000 dan 40.000. Pada tanggal 31 Agustus, pak Amin mendapatkan keuntungan 950.000 dari penjualan bako dan 700.000 dari penjualan es campur. Hasil penjualan manakah yang lebih baik pada hari terakhir bulan Agustus tersebut? Keuntungan bakso atau keuntungan es campur? Kemukakan alasannya!

Picture 3. Questions for indicators of present the results of statistical data processing

The question above (picture 3) begins with a story about Mr. Amin sells meatballs and mixed ice. During August the average profit from selling meatballs and mixed ice was 725,000 and 525,000 with standard deviations of 55,000 and 40,000, respectively. on August 31, Mr. Amin earned 950,000 from selling meatballs and 700,000 from selling mixed ice. In this question, students are asked to determine the best sale between meatballs and mixed ice on that date with their reasons.

Based on the results of student tests in answering the questions above, it is known that most students still have difficulty in answering these questions. As many as $62.50 \%$ of students incorrectly answered the questions above. From the results of examining student answer sheets, the mistake is that most students have not been able to determine the appropriate statistical measures for the case above. In addition, there are also some students who have not been able to provide interpretations and draw conclusions from the results of their calculations. The remaining $37.50 \%$ of students were right in answering the questions above. The student is able to interpret the results and make conclusions based on the results obtained.

From the results of interviews with several students, it was found that they had difficulty identifying what information was implied in the questions and what they wanted to ask. They have difficulty expressing their own opinions according to the available data or the possible predictions that exist in the data. This condition has an impact on students' difficulties in determining the appropriate solution method for the given problem. So that most students seem difficult to answer statistical literacy questions with indicators presenting the results of statistical data processing.

\section{CONCLUSION}

Based on the previous description, it was found that as much as $81.25 \%$ of students are able to read the data displayed in the form of line charts. $87.50 \%$ of students are able to present data in a diagram that is in accordance with the data provided; and only $37.50 \%$ of students are able to interpret data from a given case. Thus, it can be concluded that most of them are able to understand statistical data and present it in other forms, but they still have difficulty interpreting the results of statistical data processing 
and making conclusions based on these results. The results of this study must certainly be thought material for statistics lecturers to pay more attention to these difficulties, so that prospective teachers are more skilled in concluding statistical data.

\section{ACKNOWLEDGMENTS}

Researchers would like to thank Universitas Majalengka for providing opportunities, facilities and support so that the writing of this article is complete.

\section{REFERENCES}

Ben-Zvi, D. \& Garfield, J. (2004). Statistical literacy, reasoning, and thinking: Goals, definitions, and challenges. Dordrecht, The Netherlands: Kluwer.

Ben-Zvi, D., \& Makar, K. (2016). The Teaching and Learning of Statistics. In D. Ben-Zvi \& K. Makar (Eds.), The Teaching and Learning of Statistics. Springer International Publishing. https://doi.org/10.1007/978-3-319-23470-0

Chance, B. L. (2002). Components of statistical thinking and implications for instruction and assessment. Journal of Statistics Education. https://doi.org/10.1080/10691898.2002.11910677

delMas, R. C. (2002). Statistical literacy, reasoning and learning: A commentary. Journal of Statistics Education, 10(3). https://doi.org/10.1080/10691898.2002.11910679

for Europe, U. N. E. C., \& of the European Communities, S. O. (2007). Rural Households' Livelihood and Well-being: Statistics on Rural Development and Agriculture Household Income. United Nations Publications.

Franklin, C., Kader, G., Mewborn, D., Moreno, J., Peck, R., Perry, M., \& Scheaffer, R. (2007). Guidelines for assessment and instruction in statistics education (GAISE) report. Alexandria, VA: American Statistical Association.

Gal, I. (2002). Adults' statistical literacy: Meanings, components, responsibilities. International Statistical Review, 70(1), 1-25.

Gall, M. D., Borg, W. R., \& Gall, J. P. (1996). Educational research: An introduction. Longman Publishing.

Garfield, J. (1999). Thinking about statistical reasoning, thinking, and literacy. First Annual Roundtable on Statistical Thinking, Reasoning and Literacy (STRL-1).

Garfield, Joan, \& Gal, I. (1999). Teaching and assessing statistical reasoning. In Developing Mathematical Reasoning in Grades K-12, Chapter 18. National Council of Teachers of Mathematics.

Hayden, R. (n.d.). Planning a Statistical Literacy Program at the College Level: Musings and a Bibliography. Http://Www.Statlit.Org/Pdf/2004/HaydenASA.Pdf.

Hovermill, J., Beaudrie, B., \& Boschmans, B. (2014). Statistical literacy requirements for teachers.

Jatisunda, M. G., Nahdi, D. S., \& Suciawati, V. (2020). Literasi Statistika Mahasiswa Adminitrasi 
Statistical literacy of pre-service Islamic religious education teachers, Dede Salim Nahdi, Nurudin Araniri, Mohamad Gilar Jatisunda, Yeni Dwi Kurino, Ujiati Cahyaningsih

Publik. SJME (Supremum Journal of Mathematics Education), 4(2), 134-146. https://doi.org/10.35706/sjme.v4i2.3488

Kilpatrick, W. (1993). Why Johnny can't tell right from wrong: And what we can do about it. Simon and Schuster.

MAKAR, K., de Sousa, B., \& Gould, R. (2014). Sustainability in statistics education. Proceedings of the Ninth International Conference on Teaching Statistics (ICOTS9.

Miles, M. B., Huberman, A. M., Huberman, M. A., \& Huberman, M. (1994). Qualitative data analysis: An expanded sourcebook. sage.

Moh. Hafiyusholeh. (n.d.). Literasi Statistik Dan Urgensinya Bagi Siswa. WAHANA, Volume 64(Nomer 1).

Moreno, J. L. (2002). Toward a statistically literate citizenry: What statistics everyone should know. Proceedings of the Sixth International Conference on Teaching Statistics. Voorburg, the Netherlands: International Statistical Institute. CD ROM.

Munah Hartuti, P., \& Widyasari, H. (2016). Peran Kemampuan Awal Matematika dan Persepsi Mahasiswa pada Statistika terhadap Prestasi Belajar Statistika. SAP (Susunan Artikel Pendidikan), 1(2), 135-144. https://doi.org/10.30998/sap.v1i2.1020

Newton, J., Dietiker, L., \& Horvath, A. (2011). Teaching Statistics in School Mathematics-Challenges for Teaching and Teacher Education (C. Batanero, G. Burrill, \& C. Reading (eds.); Vol. 14). Springer Netherlands. https://doi.org/10.1007/978-94-007-1131-0

Nikiforidou, Z., Lekka, A., \& Pange, J. (2010). Statistical literacy at University level: The current trends. $\begin{array}{lllll}\text { Procedia - Social and Behavioral } & \text { Sciences, 9, 799. }\end{array}$ https://doi.org/10.1016/j.sbspro.2010.12.236

Nurizzati, Y. (2014). Penempatan Strategis Mata Kuliah Statistika Pada Kurikulum Iain Syekh Nurjati Cirebon. Eduma: Mathematics Education Learning and Teaching, 3(2). https://doi.org/10.24235/eduma.v3i2.54

of Labor. Secretary's Commission on Achieving Necessary Skills, U. S. D. (1991). What work requires of schools: A SCANS report for America 2000. Secretary's Commission on Achieving Necessary Skills, US Department of Labor.

Petty, N. W. (2010). Creating YouTube videos that engage students and enhance learning in statistics and Excel. Proceedings of the Eighth International Conference on Teaching Statistics (ICOTS8).

Pfannkuch, M., \& Wild Chris, J. (n.d.). Statistical Thinking in Empirical Enquiry. Internacional Statistical Review [Internet]. 1999 [citado: 2015 dic]; 67 (3): 223-265.

Principles, N. (2000). standards for School mathematics. Reston, Va: NCTM.

Reid, A., \& Petocz, P. (2002). Students' Conceptions of Statistics: A Phenomenographic Study. Journal of Statistics Education, 10(2). https://doi.org/10.1080/10691898.2002.11910662

Rumsey, D. J. (2002). Statistical literacy as a goal for introductory statistics courses. Journal of Statistics Education, 10(3). https://doi.org/10.1080/10691898.2002.11910678 
S Forbes, M Camden, N. P. (n.d.). Official Statistics and statistical literacy: Theyneed each othe. Tatistical Journal Of.

Sariningsih, R., \& Herdiman, I. (2017). Mengembangkan kemampuan penalaran statistik dan berpikir kreatif matematis mahasiswa di Kota Cimahi melalui pendekatan open-ended. Jurnal Riset Pendidikan Matematika, 4(2), 239. https://doi.org/10.21831/jrpm.v4i2.16685

Scheaffer, R. L. (2003). Statistics and quantitative literacy. In Quantitative Literacy: Why Numeracy Matters for Schools and Colleges (pp. 145-152). The National Council on Education and the Disciplines.

Schield, M. (2004). Information Literacy, Statistical Literacy and Data Literacy. IASSIST Quarterly. https://doi.org/10.1300/J295v03n01_22

Songsore, E., \& White, B. J. G. (2018). Students' perceptions of the future relevance of statistics after completing an online introductory statistics course. Statistics Education Research Journal, 17(2), $120-140$.

Takaria, J, \& Rumahlatu, D. (2016). The Effectiveness of CPS-ALM Model in Enhancing Statistical Literacy Ability and Self Concept of Elementary School Student Teacher. Journal of Education and Practice, 7(25)(25), 44-49.

Takaria, Johannis, \& Talakua, M. (2018). Efektivitas Model Collaborative Problem Solving (CPS) Dalam Meningkatkan Kemampuan Representasi Matematis Mahasiswa Calon Guru Sekolah Dasar. JPsd (Jurnal Pendidikan Sekolah Dasar), 4(2), 190-203.

Tishkovskaya, S., \& Lancaster, G. A. (2010). Identified Problems in Teaching and Learning Statistics. International Conference on Teaching Statistics Proceedings, 8, 2-5.

Utts, J. (2003). What educated citizens should know about statistics and probability. American Statistician. https://doi.org/10.1198/0003130031630

Wahyuni, Y., \& Fauziah. (2015). Kajian Kesulitan Mahasiswa Terhadap Mata Kuliah Statistika Elementer. LEMMA, 2(1), 76-82.

Wallman, K. K. (1993). Enhancing Statistical Literacy: Enriching Our Society. Journal of the American Statistical Association. https://doi.org/10.2307/2290686

Yotongyos, M., Traiwichitkhun, D., \& Kaemkate, W. (2015). Undergraduate Students' Statistical Literacy: A Survey Study. Procedia - Social and Behavioral Sciences, 191(July), 2731-2734. https://doi.org/10.1016/j.sbspro.2015.04.328 